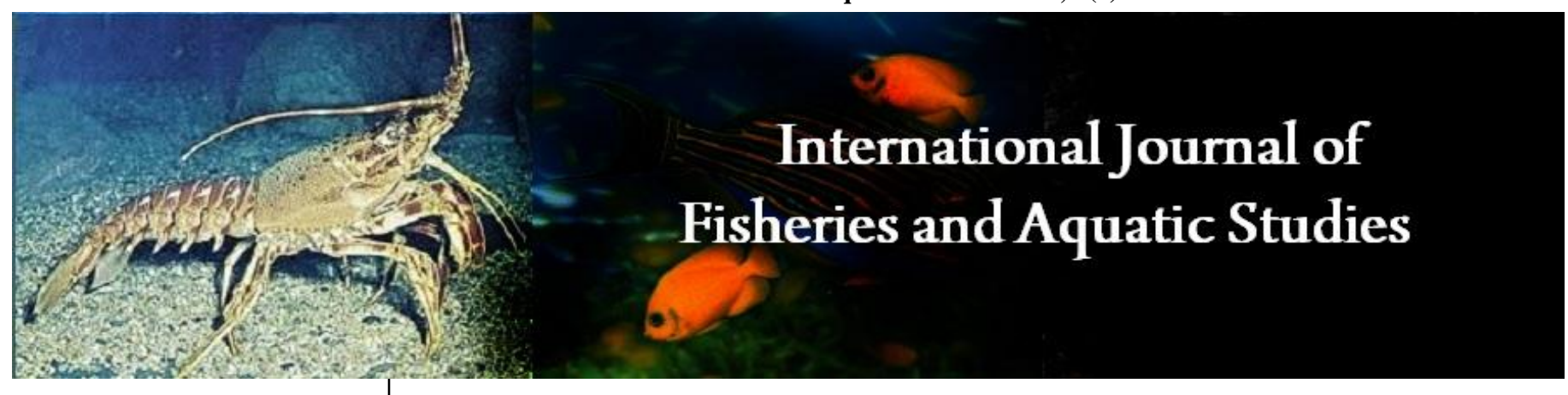

E-ISSN: 2347-5129

P-ISSN: 2394-0506

(ICV-Poland) Impact Value: 5.62

(GIF) Impact Factor: 0.549

IJFAS 2021; 9(2): 108-111

(C) 2021 IJFAS

www.fisheriesjournal.com

Received: 07-01-2021

Accepted: 10-02-2021

Agung S Abadi

Polytechnic Marine and Fisheries

of Sorong, Indonesia

Intanurfemi B Hismayasari

Polytechnic Marine and Fisheries

of Sorong, Indonesia

Waliyatun

Fish Quarantine and Quality

Control Station of Sorong,

Indonesia
Corresponding Author:

Agung S Abadi

Polytechnic Marine and Fisheries

of Sorong, Indonesia

\section{Identification of ectoparasites cause lesions in parents goldfish (Carassius auratus)}

\section{Agung S Abadi, Intanurfemi B Hismayasari and Waliyatun}

DOI: https://doi.org/10.22271/fish.2021.v9.i2b.2451

\section{Abstract}

The aim of this research was to identification the cause of lesion on the body of parents goldfish (Carassius auratus). Were cultivated fish from installation of fresh water research on Polytechnic marine and fisheries Sorong. Early diagnosis of fish limp, decreased appetite, and experienced lesion in almost all parts of the body. Fish were isolated and identified at the fish quarantine and quality control station of Sorong. The examination trats from the head, gills, body and tail. The results of identification using a microscope obtained the type of ectoparasites Dactylogyrus sp, Ergasilus sp. Gyrodactylus sp. Lernea cyprinacea, Lernea sp and Tricodina sp.

Keywords: goldfish, diagnosis, identification, ectoparasites

\section{Introduction}

The production of ornamental fish in the world of 2 / 3 total productions. In Many Countries the production of ornamental fish produced by small and medium farmers fish scale. The Raising production aquaculture caused increase disease like parasitic. The economic effect of parasitic in fish as a decrease consumtion number ${ }^{[1,2]}$.

The Study of parasitic important to be able because we can raise and sustainability of aquaculture system in the world. Failure in the parasitic management caused they have a life cycle contact on host ${ }^{[3]}$. The Parasitic is an organism who lives in depends on a host and there are two a large group that is endoparasite and ectoparasite ${ }^{[4]}$. Widely group to ectoparasite giving ill effects on fish including the ciliate, protozoa, flagellates, monogena and somecrustasea living on body of fish ${ }^{[1]}$. In addition parasitic metazoan group were also a lot of attack ornamental fish like comet gold fish Carassius auratus, angel fish Pterophylum scalare, platy fish Xiphopphorus maculates and siamese fighting fish Betta splendens ${ }^{[2]}$.

A parasitic attacked will be reduce the absorption of nutrients, The Parasitic will reduce the absorption of nutrients, a lesion, lame, the cost treatment, low production, even cause death on fish. In other the big effect can inflict as sustainability and economic viability of aquaculture [5]. Hence identification conducted to explain and prevent of occurrence of disease in a goldfish. The research was done at the station a fish quarantine and quality control of Sorong in 2020 .

\section{Materials and Methods}

\subsection{Fish cultivation}

The parents goldfish collect from fish farmers and the cultured in fresh water aquaculture installation of marine and fisheries polytechnic Sorong.the weight of male fish $70 \mathrm{gr}$, total length $15 \mathrm{~cm}$, and standart lenght $11 \mathrm{~cm}$. the female is $75 \mathrm{gr}$, a total length 14 and standart length $11 \mathrm{~cm}$.

\subsection{Necropsy and Indentification Procedure:}

The ectoparasitic collect on carp into three part thet is the head (gills), the body (dorsal, ventral and anal fin) and on the tail. Taken mucus fish by means of scrapted off is using a spatula, the dissecting set, and tweezers. Fish mucus put on an object glass then dilute by the 2-3 drops aquadest. 


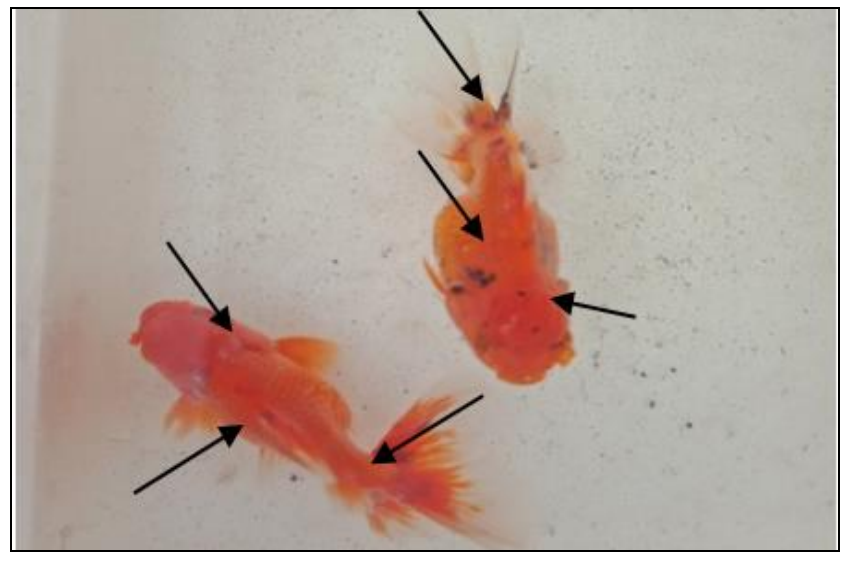

Fig 1: Goldfish (Carassius auratus)

The laid under bionocular microscope (primostar) to do observations with magnification 100-400x and identification using guidebooks pest of fish and name fish disease quarantine 2009.

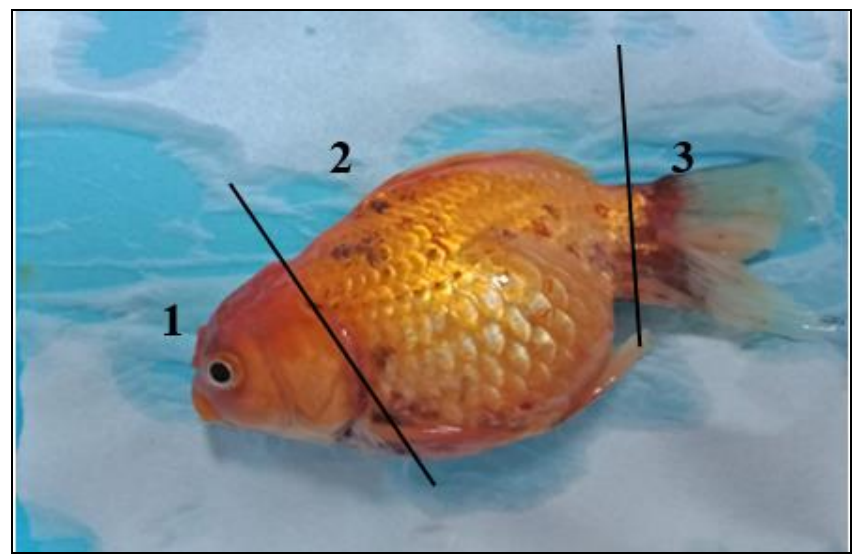

Fig 2: Parasitic cultivation

\section{Results}

\subsection{Identification and caracterisation of parasites}

The fish clinical indications illness visible at figure 1. Fish had a bruises and cuts almost all over her, starting in the head of, the body, and the tail. Moreover the fish are also decreases appetite, swimming slow and often rubbing his body in the wall and bottom ponds. On the part anal fins began damaged followed with bruises on hip the fins. The fish operculum difficult opens cause bruises and mucus offer production, and then stability swimming a disturbed. The mouth of fish had torn, so that when given feed, fish a not capable of eating normally.

Table 1: Ectoparasites collected result

\begin{tabular}{|c|c|c|c|}
\hline \multicolumn{4}{|c|}{$\begin{array}{c}\text { Identification Parasitic cause Lession on Goldfish } \\
\text { (Carassius auratus } \text { ) }\end{array}$} \\
\hline No & Cultivated location & Parasites species & total \\
\hline \multirow{4}{*}{1} & Head & Lernaea cyprinacea & 6 \\
\cline { 2 - 4 } & Gills & Dactilogyrus sp & 126 \\
\cline { 2 - 4 } & & Gyrodactilus cyprinid & 65 \\
\cline { 2 - 4 } & Mouth & Gyrodactilus cyprinid & 15 \\
\hline \multirow{3}{*}{2} & \multirow{2}{*}{ Body } & $\begin{array}{c}\text { Lernaaea cyprinacea } \\
\text { youth phase }\end{array}$ & 85 \\
\cline { 2 - 4 } & & Trichodina sp & 60 \\
\cline { 2 - 4 } & Dorsal & Lernea cyprinacea & 4 \\
\cline { 2 - 4 } & Ventral & Lernaea cyprinacea & 3 \\
\hline 3 & Tail & Dactilogyrus sp & 60 \\
\cline { 2 - 4 } & & & \\
\hline
\end{tabular}

The identification on gills we found 126 species Dactilogyrus sp and 65 Species Gyrodactilus cyprini (Platyhelminthes), while in the head we found of 6 Lernea cyprinacea (Crustacea). have a 15 Gyrodactilus cyprini on mouth. On the body more a Lernea cyprinacea on youth phase and adult phase and there are 60 species of Trichodina sp (Ciliphora). Whereas in the tails we found Lernaea cyprinacea 3 species and more often of Dactilogyrus 60 species. Three groups of parasitic attack in different fish organs. The fish is potentially host of parasites either at the time of the condition active or inactive.

The fish parasites were more found on gills whit percentage $44 \%$, on body $34 \%$, tail $15 \%$, mouth $4 \%$, and then head, ventral fin, and dorsal fin all $1 \%$. The parasitic species mayor of Dactilogyrus sp 42\%, Gyrodactilus cyprinid $21 \%$, Lernaea cyorinacea youth fase 19\%, Trichordina sp 14\%, and Lernaea cyprinacea $4 \%$.

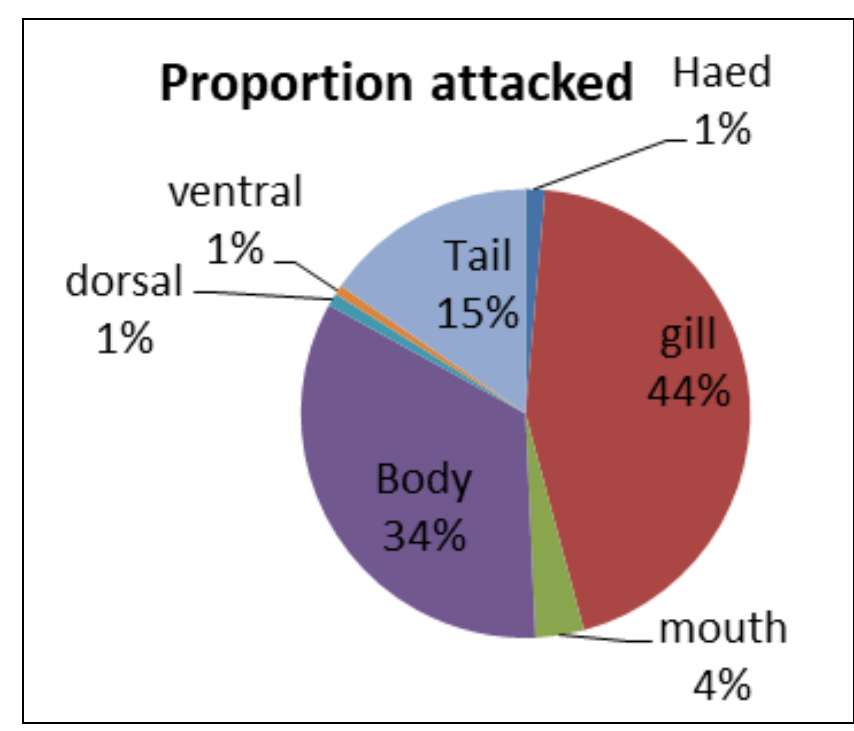

Fig 3: Proportion attacked

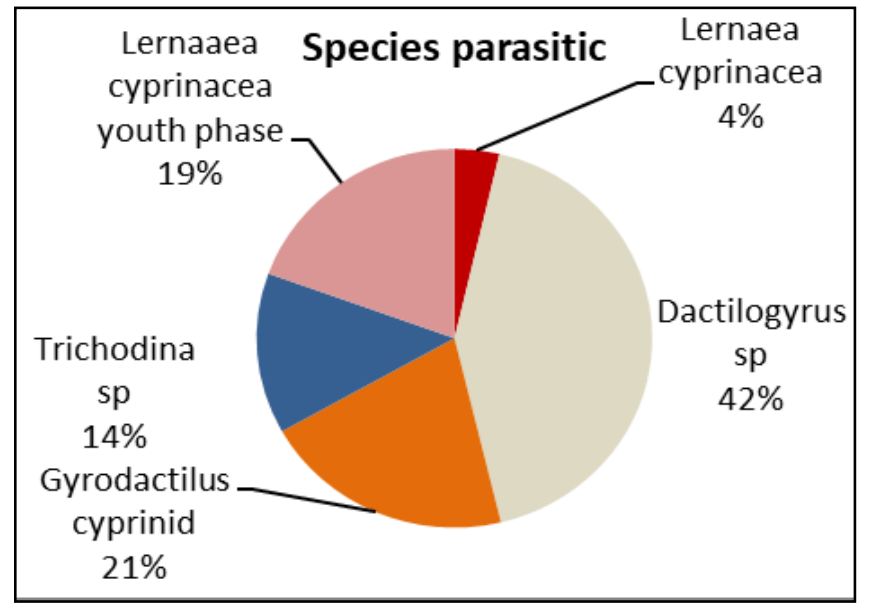

Fig 4: Proportion species parasitic

\section{Discussion}

Parasites can attack on individual fish or directly at the cultivation of many fishes depends on the environmental condition [6]. Many attacks of parasites is not only causes environmental change in aquaculture but in an inactive parasitic also allows. Parasitic infection occurs because of differences in feed, feed quality, fish age, fish size, water condition, and activites of aquaculture ${ }^{[7]}$. The transmission of parasitic on a host can be caused of habits, mannerisms, and 
density, it's also environmental factor such as temperature and the depth of the ponds ${ }^{[3]}$. explain by F. Iyaji and J. Eyo ${ }^{[8]}$. Parasitic when infect a cell usually will impact existence lesion in the bodies. Many species parasites stay and live on the gills especially of fresh water fish ${ }^{[9]}$. Ambush of parasite in gills will cause inhibition on oxygen exchange and become reason presence of bacteria pathogen ${ }^{[10]}$. The attacking parasitic on fish its also will effecting in the sexual ability and gonadal maturity ${ }^{[6]}$. Although in several studies one species can attack on some host an organ ${ }^{[11]}$.
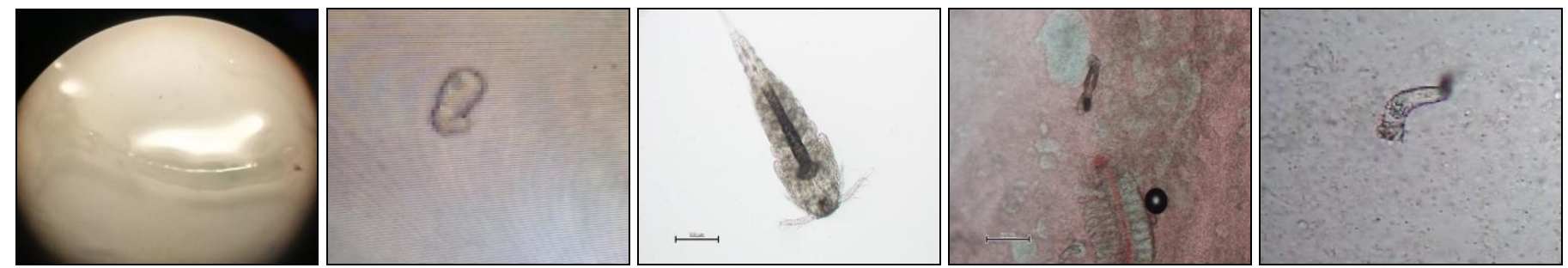

Fig 5: a clue: A, Lerneae cyprinaceae 10x, B. Trichodina sp 100x, C. Lerneae youth phase 100x, D. Gyrodactilus sp 100x, E. Dactylogyrus sp $100 \mathrm{x}$

Many 126 parasites of Dactylogyrus sp have found, where live at gills. These parasites would absorb nutrients whit an anchor and sucker causing hemorrhage and gills injuries ${ }^{[12]}$. Another effect of infection it to reduce immune system and cause stress, so that the risk of infection pathogenic increased [13]. In Brazil many species parasitic found on the gills, whether it is on fresh water, brackish, and then marine fish [14].

Species parasite Lernaea cyprinacea is an indigenous parasite in goldfish in other the new fish can be able a vector ${ }^{[13]}$, [15]. Lernaea parasites a found in all areas of the fish body, they attach using anchor mouth, and fangs. Parasite will be suck blood and mucus host. The danger of Lernaea parasites damaging the skin tissue, in addition to causing fish to die, especially in teh jouvenil phase. Lesion cause Lernaea will provide access to growth of bacterial pathogen, viruses, and fungi ${ }^{[16]}$.

The parasitic species like Gyrodactilus sp and Trichodina sp it a secondary parasite is mean they can infect the host if another parasite have infected, other contamination from environment, the stability ecological disturbed, like temperature change and then carried agents off disease in culture media caused the attacking secondary parasite excelsior. [17]. The live optimally of Gyrodactilus on temperate $21-27,5{ }^{0} \mathrm{C}{ }^{[18]}$. The clinical indication unsure like a bruised on bodies, shell, fins, and tails whit more mucus production. The Gyrodactilus and Trichodina have an opisthaptor. The opisthaptor used to penetrate host tissue also whit containing sucker organ, and then they have a marginal hooks functions for destroy the ephitelium cells. When infection was going to happen change haemoglobin and haematokrit ${ }^{[19]}$.

\section{Conclusion}

The Ectoparasite in fish can cause infection, tissue damage and pathogens attacked. Species ectoparasite cause lesion is a Lernaea cyprinacea and Trichodina sp. Whereas gills swollen is a Dactylogyrus dan Gyrodactilus cyprini.

\section{References}

1. Najm M, Fakhar M. "Helminthic Parasites as Heavy Metal Bioindicators in Aquatic Ecosystems," Med. Lab. J 2015;9(4):26-32.

2. Florindo MC. et al., "Protozoan parasites of freshwater ornamental fish 2017;45(5):948-956.

3. Minaya D, Alvariño L, Rodríguez-Santiago MA, Iannacone J. "Community of eumetazoan parasites in ocean whitefish Caulolatilus princeps (Jenyns, 1840)
(Perciformes, Malacanthidae) off north Peru," Panam. J Aquat. Sci 2020;15(2):133-142.

4. Sauyai K, Longdong SNJ, Kolopita MEF. "Identification of Parasites in Grouper, Plectropomus leopardus," Budid. Perair 2014;2(3):76-83.

5. Onara DF et al., "Differential transcription of multiple forms of alpha-2-macroglobulin in carp (Cyprinus carpio) infected with parasites," Dev. Comp. Immunol 2008;32(4):339-347.

6. Barber I, Hoare D, Krause J. "Effects of parasites on fish behaviour: a review and evolutionary perspective," Rev. Fish Biol. Fish 2000;10:131-165.

7. Handayani R, Adiputra YT, Wardiyono. "Identification and diversity of Parasite in Goldfish (Carrasius auratus) and Goldfish (Cyprinus carpio) from Lampung and Out of Lampung," Aquasains 2014;1:149-156.

8. Iyaji F, Eyo J Parasites and their Freshwater Fish Host," Bio-Research 2008;6:328-338.

9. Raissy M, Ansari M, Lashkari A, Jalali B. Occurrence of parasites in selected fish species in Gandoman Lagoon, Iran 2010;9(3):464-471.

10. Mf WP et al., "Protozoan and metazoan parasites of Nile tilapia Oreochromis niloticus cultured in Brazil Parásitos protozoarios y metazoarios de la tilapia del Nilo," Rev.MVZ Cordoba 2012;17(1):2812-2819.

11. Alifuddin M, Hadiroseyani Y, Ohoiulun I. "Parasites in Fresh Water Ornamental Fish (Cupang, Guppy and Rainbow Fish)," J. Akuakultur Indones 2003;2(2):93100.

12. Akbar J. "Identification of Parasites in Betokfish (Anabas testudieus)," Bioscientia 2011;2(36-45):36-40.

13. Rohlenová K, Morand S, Hyrl P, Tolarová S, Flajhans M, Imková A. "Are fish immune systems really affected by parasites? an immunoecological study of common carp (Cyprinus carpio)," Parasites and Vectors 2021;4(1):118.

14. Grande R, De Ondina C, Costeiros E. "Gill parasites from Caranx latus (Perciformes, Carangidae) from Northeastern Coast of Brazil and a new host record to the monogenoid Protomicrocotyle mirabilis (Monogenoidea, protomicrocotylidae) and Caligus chorinemi (Copepoda, Caligidae) 2020:15;151-162.

15. Boane C, Cruz C, Saraiva A. "Metazoan parasites of Cyprinus carpio L. (Cyprinidae) from Mozambique," Aquaculture 2008;284(1-4):59-61, doi: 10.1016/j.aquaculture.2008.07.037.

16. Gaznegh SF, Azadikhah D. "First Report of Infection with Lernea (Linnaeus, 1758) in Rainbow Trout Cage 
Culture in Iran 2014;3(3):242-248.

17. Salinas ZA, Babini MS, Grenat PR, Biolé FG, Martino AL, Salas NE. "Effect of parasitism of Lernaea cyprinacea on tadpoles of the invasive species Lithobates catesbeianus," Heliyon 2019;5(6):1-6.

18. Scott M, Nokes JD. "Temperature-dependent reproduction and survival of Gyrodactylus bullatarudis (Monogenea) on guppies (Poecilia reticulata)," Parasitology 1984;89(2):221-228.

19. Martins M, MN, NG, MP R. First record of Trichodina heterodentata (Ciliophora: Trichodinidae) from channel catfish, Ictalurus punctatus cultivated in Brazil, Braz. J Biol 2010;70(3):637-644. 